\title{
IMPLEMENTASI TEKNOLOGI BUSINESS PROCESS MODEL NOTATION (BPMN), TEKS, FLOWCHART DAN RICH PICTURE PADA BISNIS STARTUP
}

\author{
Rizqiyatul Khoiriyah ${ }^{1}$, Aan Jelli Priana ${ }^{2}$ \\ ${ }^{1}$ Program Studi Sistem Informasi, Universitas Gajayana \\ Jl. Mertojoyo Blok L, Merjosari, Malang \\ ${ }^{2}$ Program Studi Sistem Informasi, Universitas Kanjuruhan \\ J1. S. Supriadi No.48 Sukun, Malang \\ rizqiyatuleunigamalang.ac.idㄹ, ms.aanjpegmail.com²
}

\begin{abstract}
Business processes are very influential in the continuity of a company, including CV. SLC. However, the business processes that occur at CV. SLC has not been well documented so that in practice it is often applied differently by employees. Even though the company also wants to evaluate the performance and performance of the company. From these problems, a description and analysis of business processes are made using several diagrams, namely text form, rich picture flow, flowchart, and Business Process Model Notation (BPMN). The results of the analysis show that understanding business processes is easier to understand if it is modeled with a rich picture/flowchart/notation model compared to verbal / text. However, it is easier to analyze and evaluate in more depth when using the Business Process Model Notation (BPMN). The results of this business process analysis are expected to be implemented following the business reality to improve the performance and performance of CV. SLC. Keywords - Business Process, Startup, Rich Picture, Business Process Model Notation (BPMN).

Abstrak - Proses bisnis sangat berpengaruh terhadap kelangsungan suatu perusahaan, tidak terkecuali pada CV. Siplho Corporation (SLC). Namun, proses bisnis yang terjadi di CV. SLC belum terdokumentasikan dengan baik, sehingga pada pelaksanaanya seringkali diterapkan secara berbeda oleh pegawai. Padahal perusahaan juga ingin mengevaluasi terhadap kinerja dan performa perusahaannya. Dari permasalahan tersebut maka dibuatlah gambaran dan analisis proses bisnis menggunakan beberapa diagram yaitu bentuk teks, alur rich picture, flowchart dan Business Process Model Notation (BPMN). Hasil analisis menunjukkan bahwa pemahaman proses bisnis lebih mudah dipahami jika dimodelkan dengan alur gambar/diagram alir/notasi model dibandingkan dengan verbal / teks. Namun lebih mudah dianalisis dan evaluasi lebih mendalam bila menggunakan Business Process Model Notation (BPMN). Hasil analisis proses bisnis ini diharapkan nantinya dapat diimplementasikan sesuai dengan kenyataan bisnis tersebut agar dapat meningkatkan kinerja dan performa CV. SLC.
\end{abstract}

Kata Kunci - Proses Bisnis, Startup, Rich Picture, Business Process Model Notation (BPMN).

\section{PENDAHULUAN}

Perkembangan sistem dan teknologi informasi di era digital ini telah berperan dalam penyelenggaraan proses bisnis suatu organisasi. Sebuah sistem informasi mampu menjalankan komputasi numerik berkecepatan dan bervolume tinggi, serta mampu menyimpan informasi dalam jumlah besar dalam ruang yang kecil dan dapat diakses kapan pun dengan mudah [1].

Suatu proses bisnis adalah aktivitas yang terukur dan terstruktur untuk memproduksi output tertentu untuk kalangan pelanggan tertentu. Dengan menganalisis proses bisnis, perusahaan akan lebih mudah untuk memahami dan menuju kearah efisiensi dalam proses untuk memperoleh keuntungan yang didapatkan [2][3]. Hal ini sangatlah berpengaruh terhadap kelangsungan suatu bisnis, tidak terkecuali pada bisnis startup yang saat ini sedang menjamur di Indonesia.
Sebagai enabler esensial, teknologi informasi telah membuat orang-orang melakukan pekerjaan melalui cara-cara yang berbeda. Hal ini pula membuat cara kerja suatu organisasi pun beralih dari aturan lama menuju pembaruan dalam proses bisnisnya [4].

Menjamurnya pengguna internet untuk bisnis mendorong lahirnya berbagai bisnis baru yang banyak dikatakan sebagai "start up business". Bisnis start up merupakan sebuah usaha yang baru didirikan dan masih pada tahap pengembangan serta penelitian untuk mencari potensi pasar. Bisnis startup ini pula tergolong dalam bidang usaha teknologi dan informasi. Di Indonesia sendiri, Bukalapak, Gojek, Tokopedia, dan sebagainya merupakan contoh bisnis startup yang popular [5].

CV. Siplho Corporation (SLC) merupakan usaha startup yang bergerak di bidang trade and consultant IT. Salah satu unit pelayanannya adalah "Service dan Maintenance". Selama ini proses bisnis yang terjadi di SLC belum terdokumentasikan, sehingga pada pelaksanaanya seringkali proses bisnisnya dipahami 
dan diterapkan secara berbeda oleh pegawai sehingga seringkali menimbulkan problem tersendiri bagi pelayanan service dan maintenance untuk Customer.

Problem yang muncul dari adanya perbedaan pemahaman dan penerapan proses bisnis tersebut menyebabkan beberapa keluhan dari Customer seperti pengecekan dan konfirmasi laptop sering terlambat, kesalahpahaman dalam perihal kesepakatan proses, waktu dan biaya pengerjaan dari pegawai ke Customer, sehingga akan mempengaruhi perilaku organisasi serta dampaknya terhadap organisasi baik dari sisi performa kinerja individu maupun kelompok.

Supaya proses bisnis tersebut dapat dikomunikasikan dan dipahami dengan mudah ke semua pelaku bisnis maka diperlukan sebuah teknik pemodelan proses bisnis yang praktis namun cukup representatif yang dapat mewakili proses sebenarnya. Analisis dan pemodelan proses bisnis sendiri digunakan untuk pemahaman dan komunikasi yang lebih baik terhadap proses-proses yang terjadi dalam perusahaan [6][7].

Untuk menganalisis sekaligus memodelkan proses bisnis dapat melalui pendeskripsian teks maupun penggambaran menggunakan diagram. Beberapa diagram untuk memodelkan proses bisnis diantaranya adalah flowchart, rich picture dan BPMN. Salah satu bentuk pemodelan populer dan banyak di adopsi oleh organisasi adalah Business Process Modeling Notation (BPMN) yang dirilis pertama kali di tahun 2004 [8][9][10].

Berdasarkan uraian di atas maka akan dilakukan penelitian tentang bagaimana implementasi BPMN, teks, flowchart dan rich picture dapat diterapkan pada CV. SLC. Proses bisnis yang ada di CV.SLC yang akan dipetakan dalam beberapa diagram pemodelan tersebut dilihat dari sisi pegawai yaitu admin dan teknisi, sisi owner dan sisi customer.

\section{METODE PENELITIAN}

\section{A. Tahapan Penelitian}

Metodologi dalam penelitian ini terbagi menjadi beberapa tahapan sebagai berikut :

1. Studi Literatur

Studi literatur merupakan pencarian atas referensi teori yang relevan dengan kasus dan permasalahan yang ada. Studi literatur dilakukan dengan mencari referensi tentang pemodelan bisnis menggunakan BPMN melalui bahan ajar kuliah, buku dan media internet. Studi literatur dibutuhkan untuk memperkuat permasalahan sekaligus digunakan untuk dasar teori serta untuk melakukan desain pemodelan BPMN.

2. Wawancara

Metode pengumpulan data dengan wawancara, yaitu upaya mendapatkan informasi dengan bertanya langsung kepada responden. Wawancara merupakan salah satu bagian terpenting dari setiap survey. Tanpa adanya wawancara, peneliti akan kehilangan informasi yang hanya dapat diperoleh dengan jalan bertanya langsung kepada responden. Wawancara diperlukan untuk menggali informasi tentang proses bisnis yang dilakukan oleh pemilik dan pelaku usaha (stakeholder) di CV. SLC.

3. Observasi

Observasi dapat dengan cara melihat secara langsung apa saja proses bisnis oleh stakeholder di CV. SLC. Tujuan observasi adalah mendukung informasi yang diberikan dari hasil wawancara.

\section{Sketsa Proses Bisnis}

Sketsa proses bisnis akan menggambarkan kondisi proses bisnis layanan servis di CV. SLC menggunakan high level diagram BPMN sebagai dasar implementasi diagram proses bisnis yang akan digunakan perusahaan.

5. Verifikasi Sketsa

Menunjukkan sketsa proses bisnis kepada CEO CV. SLC untuk dievaluasi jika ada proses bisnis yang belum merepresentasikan kondisi bisnis yang terjadi secara nyata.

6. Design Implementasi Proses Bisnis

Melakukan rekontruksi BPMN yang telah disepakati dari hasil verifikasi sketsa awal. Kemudian menjabarkan low level diagram BPMN menjadi lebih detail

7. Validasi Proses Bisnis

Kesesuaian BPMN dengan Bisnis Instance yang terjadi di SLC

\section{B. Deskripsi Penelitian}

Pada penelitian ini menggunakan penelitian jenis kualitatif yaitu penelitian tentang riset yang bersifat deskriptif dan cenderung menggunakan analisis secara induktif [11]. Pendekatan penelitian yaitu menggunakan studi kasus yaitu penelitian yang dilakukan pemeriksaan longitudinal mendalam terhadap suatu keadaan atau kejadian yang disebut sebagai kasus dengan menggunakan cara-cara yang sistematis dalam melakukan pengamatan, pengumpulan data, analisis informasi, dan pelaporan hasilnya. Bertempat di CV. SLC Corporation di Surabaya. Pengumpulan data dilakukan melalui interview atau wawancara kepada 3 macam informan yaitu Owner, Pegawai dan Customer. Pada penelitian ini digunakan sebagai instrument adalah data servis, prosedur layanan, SOP, data pegawai di CV. SLC Corporation. Selain itu yang juga penting adalah Tim Peneliti itu sendiri..

\section{HASIL DAN PEMBAHASAN}

Pada bagian ini diawali dari identifikasi proses bisnis yang ada di CV. SLC. Kemudian dari proses bisnis tersebut akan dilakukan skenario proses bisnis berdasarkan layanan dalam menangani keluhan customer. Nantinya akan disusunlah alur prose dengan berbagai versi tampilan. Dan kemudian keseluruhan prose tersebut dievaluasi serta dilihat bagaimana pengaruh implementasi BPMN di CV. SLC. 
A. Proses Bisnis di CV. SLC SLC:

Berikut ini adalah gambaran proses bisnis di CV.

1. Proses Bisnis Customer

a. Customer yang memiliki permasalahan dengan laptopnya datang ke kantor SLC, kemudian menjelaskan permasalahanya untuk mendapatkan diagnosnga awal.

b. Customer mendapatkan nota terima barang setelah setuju untuk dilakukan pengecekan agar diketahui diagnosa akhir kerusakan.

c. Customer mendapatkan laporan hasil pengecekan kemudian memberikan keputusan / persetujuan pengerjaan lanjutan

d. Customer mendapatkan konfirmasi status pengerjaan laptop

a. Customer menyerahkan nota terima kemudian mendapatkan faktur (invoice)

b. Customer melakukan pembayaran biaya servis lalu mendapatkan laptopnya kembali.

\section{Proses Bisnis Admin}

a. Admin menyapa Customer yang datang ke kantor kemudian memberikan layanan konsultasi terhadap problem laptop.

b. Admin menawarkan proses pengecekan selama 2 hari kemudian membuat dan memberikan nota terima barang kepada Customer.

c. Admin mendistribusikan layanan pengecekan kepada teknisi untuk memastikan diagnosa akhir.

d. Admin menerima laporan hasil pengecekan dari teknisi untuk memberikan laporan hasil pengecekan kepada Customer.

e. Admin memberikan perintah pengerjaan lanjutan kepada teknisi setelah mendapatkan persetujuan pengerjaan dari Customer.

f. Admin menerima laporan hasil pengerjaan dari teknisi

g. Admin memberikan konfirmasi status pengerjaan laptop Customer

h. Admin meminta nota terima kemudian membuat faktur (invoice)

i. Admin menerima pembayaran biaya service lalu menyerahkan laptop kepada Customer.

3. Proses Bisnis Teknisi

a. Teknisi mendapatkan distribusi pengecekan laptop dari admin.

b. Teknisi melakukan pengecekan sesuai dengan diagnosa awal dan prosedur pengecekan.

c. Teknisi memberikan laporan hasil pengecekan kepada admin.

d. Teknisi melakukan pengerjaan lanjutan setalah mendapatkan instruksi dari admin.

e. Teknisi memberikan laporan hasil pengerjaan kepada admin.

\section{B. Skenario Proses Bisnis di CV. SLC}

Skenario proses bisnis CV.SLC dibagi menjadi 3 skenario dengan jenis kerusakan berbeda - beda sehingga penanganannya juga berberbeda. Berikut ini adalah skenario proses bisnis di CV. SLC:

Tabel 1. Skenario Proses Bisnis

\begin{tabular}{|c|l|c|c|c|}
\hline Skenario & \multicolumn{1}{|c|}{$\begin{array}{c}\text { Jenis } \\
\text { Kerusakan }\end{array}$} & $\begin{array}{c}\text { Tingkat } \\
\text { Kerusakan }\end{array}$ & $\begin{array}{c}\text { Waktu } \\
\text { Pengecekan }\end{array}$ & $\begin{array}{c}\text { Waktu } \\
\text { Pengerjaan }\end{array}$ \\
\hline I & $\begin{array}{l}\text { Scanning, } \\
\text { Install } \\
\text { Ulang, } \\
\text { Overheat }\end{array}$ & Ringan & $\begin{array}{c}\text { Maks. 2 } \\
\text { hari }\end{array}$ & $\begin{array}{c}\text { Maks. 2 hari } \\
\text { (terhitung } \\
\text { sejak cek) }\end{array}$ \\
\hline II & $\begin{array}{l}\text { Chipset } \\
\text { VGA, IC } \\
\text { Power }\end{array}$ & Sedang & $\begin{array}{c}\text { Maks. 2 } \\
\text { hari }\end{array}$ & $\begin{array}{c}\text { Maks. 10 hari } \\
\text { (terhitung } \\
\text { sejak cek) }\end{array}$ \\
\hline III & Mothetboard & Berat & $\begin{array}{c}\text { Min. 10 } \\
\text { hari }\end{array}$ & $\begin{array}{c}\text { Maks. 30 hari } \\
\text { (terhitung } \\
\text { sejak cek) }\end{array}$ \\
& & & & \multicolumn{2}{|c}{} \\
\end{tabular}

C. Analisis Proses Bisnis di CV. SLC

1. Analisis dengan Deskripsi Teks

Pelanggan datang ke kantor dengan membawa permasalahan laptopnya untuk mendapatkan layanan konsultasi di SIPLHO. Admin kemudian menanyakan kepada pelanggan apakah setuju untuk dilakukan proses pengecekan. Jika setuju, maka pelanggan menyerahkan laptopnya, kemudia admin membuat dan memberikan nota terima barang kepada pelanggan yang selanjutnya akan dilakukan proses pengecekan oleh teknisi. Jika tidak setuju, maka pelanggan bisa membawa laptopnya terlebih dahulu dan pergi meninggalkan kantor.

Setelah proses pengecekan selesai, maka teknisi memberikan laporan hasil pengecekan kepada admin yang selanjutnya diteruskan kepada pelanggan. Pelanggan memberikan persetujuan kepada admin apakah proses pengerjaan akan dilanjutkan atau tidak. Jika setuju, maka proses pengerjaan dilanjutkan untuk segera diselesaikan. Jika tidak setuju, maka proses pengerjaan dibatalkan kemudian pelanggan bisa mengambil laptopnya dan pergi meninggalkan kantor.

Setelah proses pengerjaan selesai, maka teknisi memberikan laporan status pekerjaan kepada admin yang selanjutnya diteruskan kepada pelanggan. Pelanggan kemudian melakukan transaksi pembayaran biaya service kepada admin. Setelah transaksi selesai dilakukan, maka admin menyerahkan kembali laptopnya kepada pelanggan. Pelanggan bisa meninggalkan kantor dengan membawa laptopnya yang sudah normal.

\section{Gambar 1. Analisis dengan Deskripsi Teks}

2. Analisis dan Pemodelan Menggunakan Rich Picture

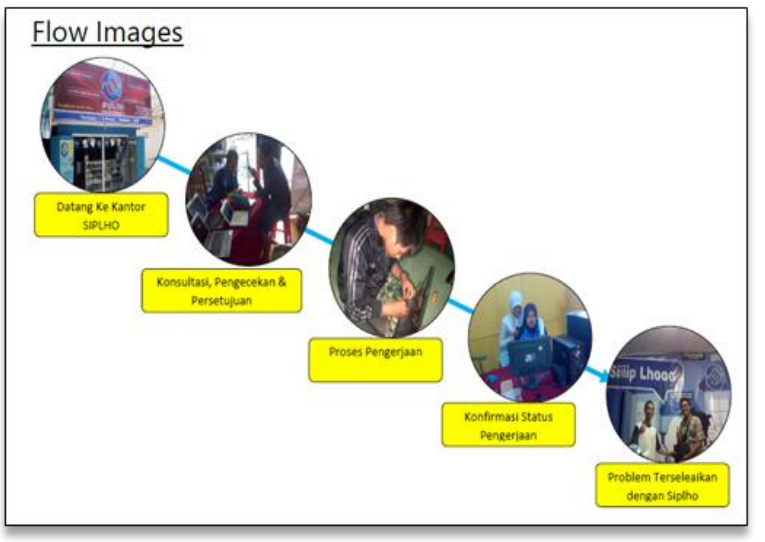

Gambar 2. Analisis dan Pemodelan Menggunakan Rich Picture 
3. Analisis dan Pemodelan Menggunakan Flowchart

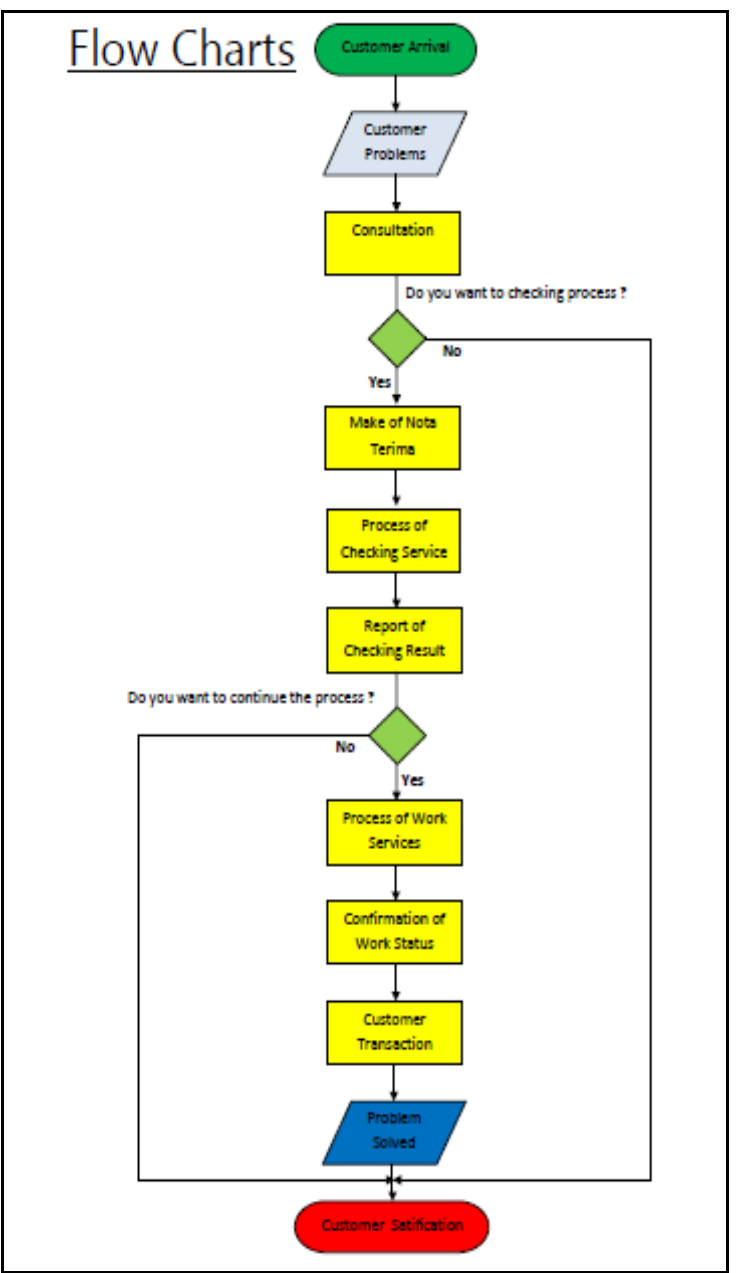

Gambar 3. Analisis dan Pemodelan Menggunakan Flowchart

4. Analisis dan Pemodelan Menggunakan Business Process Modeling Notation (BPMN)

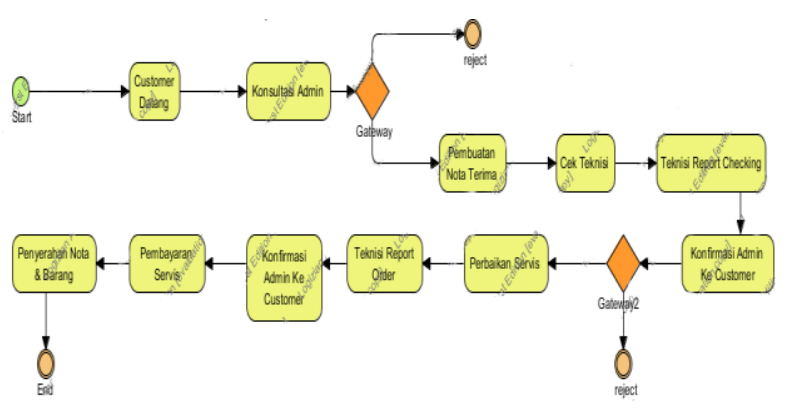

Gambar 4. Analisis \& Pemodelan Menggunakan BPMN

Pada gambar 4 menjelaskan tentang proses bisnis yang digambarkan melalui BPMN. Langkah setiap proses bisnis dapat dengan jelas dan mudah dipahami karena memodelkan dengan sederhana namun tersampaikan kebutuhan informasi langkah-langkah proses bisnis masing-masing.

\section{Hasil Penelitian}

Dari hasil wawancara terhadap 3 pelaku bisnis yang ada di CV. SLC, maka didapatkan hasil sebagai berikut:

\section{Customer}

Pertanyaan: Menurut anda, lebih mudah manakah anda dalam memahami prosedur layanan di SLC ?

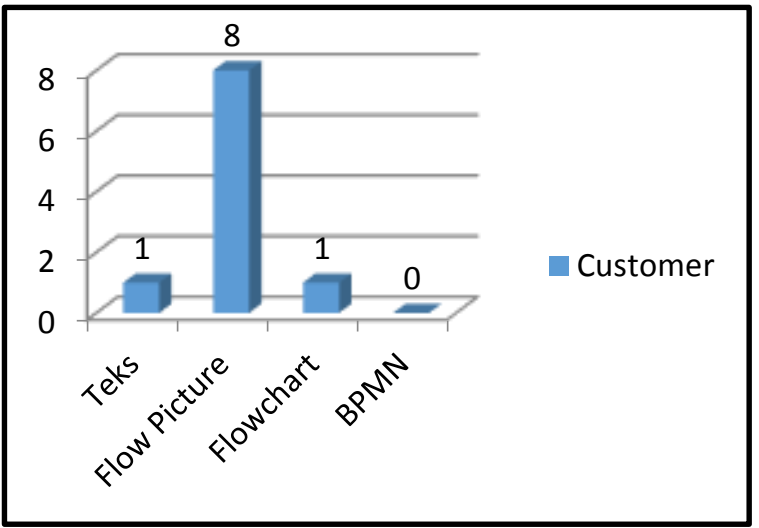

Gambar 5. Grafik Hasil Wawancara Customer

Gambar 5 menunjukkan dari 10 Customer, 8 orang memilih flow picture, 1 orang memilih teks, 1 orang memilih flowchart dan tidak ada yang memilih BPMN.

2. Pegawai

Pertanyaan:

a. Dari gambar BPMN ini, apakah anda dapat mengerti alur proses bisnis yang terjadi di SLC ?

b. Dengan adanya BPMN, apakah dapat membantu mengurangi masalah koordinasi antar pelaku bisnis ?

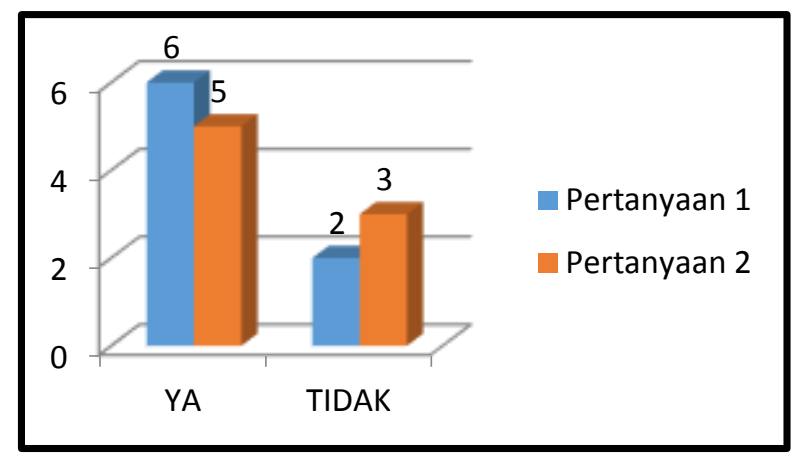

Gambar 6. Grafik Hasil Wawancara Pegawai

Pada gambar 6 menunjukkan dari 10 Customer, 8 orang memilih flow picture, 1 orang memilih teks, 1 orang memilih flowchart dan tidak ada yang memilih BPMN. 
3. Owner

Pertanyaan:

a. Dari gambar BPMN ini, apakah dapat mengarahkan kinerja masing-masing pegawai anda (membantu proses kontroling bisnis) ?

b. Dengan adanya BPMN, menurut anda apakah dapat membantu mengevaluasi jalannya proses bisnis di perusahaan anda?

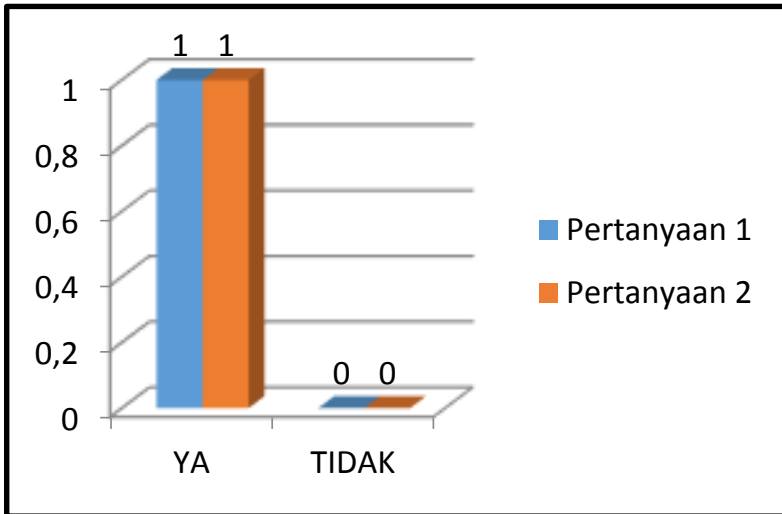

Gambar 7. Grafik Hasil Wawancara Owner

Pada gambar 7 menunjukkan bahwa Owner dapat mengarahkan dan membantu evaluasi jalannya proses bisnis dengan adanya BPMN.

\section{E. Perbedaan Implementasi BPMN}

Dari hasil wawancara terhadap 3 pelaku bisnis yang ada di CV. SLC, maka didapatkan hasil sebagai berikut:

Tabel 2. Perbedaan Implementasi BPMN

\begin{tabular}{|c|c|c|c|c|}
\hline \multirow[t]{2}{*}{ Aspek } & \multicolumn{2}{|c|}{ Sebelum } & \multicolumn{2}{|c|}{ Sesudah } \\
\hline & Teks & $\begin{array}{c}\text { Flow } \\
\text { Picture }\end{array}$ & $\begin{array}{l}\text { Flow } \\
\text { Chart }\end{array}$ & BPMN \\
\hline Pemahaman & $\begin{array}{l}\text { Lama } \\
\text { untuk } \\
\text { dipaham } \\
\text { i karena } \\
\text { masih } \\
\text { susah } \\
\text { untuk } \\
\text { dibayan } \\
\text { gkan } \\
\text { alur } \\
\text { prosesn } \\
\text { ya }\end{array}$ & $\begin{array}{l}\text { Lebih } \\
\text { mudah } \\
\text { dipahami } \\
\text { dibandingk } \\
\text { an dengan } \\
\text { teks karena } \\
\text { alurnya } \\
\text { sudah bisa } \\
\text { tergambar } \\
\text { secara } \\
\text { umum }\end{array}$ & $\begin{array}{l}\text { Lebih } \\
\text { mudah } \\
\text { dipahami } \\
\text { dibanding } \\
\text { kan } \\
\text { dengan } \\
\text { teks, } \\
\text { cocok } \\
\text { untuk } \\
\text { keseluruha } \\
\text { n pegawai } \\
\text { tetapi } \\
\text { belum } \\
\text { spesifik. }\end{array}$ & $\begin{array}{l}\text { Lebih mudah } \\
\text { dipahami } \\
\text { dari } \\
\text { ketiganya. } \\
\text { Lebih cocok } \\
\text { untuk } \\
\text { pemilik } \\
\text { bisnis dalam } \\
\text { mengarahka } \\
\text { n kerja } \\
\text { masing- } \\
\text { masing } \\
\text { pegawainya }\end{array}$ \\
\hline
\end{tabular}

Tabel 2. (lanjutan)

\begin{tabular}{|c|c|c|c|c|}
\hline \multirow[t]{2}{*}{ Aspek } & \multicolumn{2}{|c|}{ Sebelum } & \multicolumn{2}{|c|}{ Sesudah } \\
\hline & Teks & $\begin{array}{l}\text { Flow } \\
\text { Picture }\end{array}$ & Flow Chart & BPMN \\
\hline Pelaksanaan & $\begin{array}{l}\text { Berbeda } \\
\text { antara } \\
\text { pegawai } \\
\text { yang } \\
\text { satu } \\
\text { dengan } \\
\text { yang } \\
\text { lain. } \\
\text { Seringk } \\
\text { ali } \\
\text { menyeb } \\
\text { a bkan } \\
\text { permasa } \\
\text { lahan } \\
\text { baik } \\
\text { dari sisi } \\
\text { internal } \\
\text { dan } \\
\text { eksterna } \\
\text { l. }\end{array}$ & $\begin{array}{l}\text { Memperm } \\
\text { udah } \\
\text { pemahama } \\
\text { n dari sisi } \\
\text { Customer } \\
\text { saja }\end{array}$ & $\begin{array}{l}\text { Alur } \\
\text { Koordinasi } \\
\text { belum } \\
\text { tergambark } \\
\text { an secara } \\
\text { jelas } \\
\text { sehingga } \\
\text { alur kerja } \\
\text { dalam } \\
\text { memberika } \\
\text { n pelayanan } \\
\text { terkadang } \\
\text { mengalami } \\
\text { permasalah } \\
\text { an di sisi } \\
\text { internal } \\
\text { yang } \\
\text { berdampak } \\
\text { tidak } \\
\text { langsung } \\
\text { kepada } \\
\text { Customer. }\end{array}$ & $\begin{array}{l}\text { tahapan dan } \\
\text { koordinasi } \\
\text { lebih details, } \\
\text { spesifik dan } \\
\text { kompleks } \\
\text { sehingga } \\
\text { bisa } \\
\text { digunakan } \\
\text { untuk } \\
\text { monitoring, } \\
\text { controlling } \\
\text { dan evaluasi. }\end{array}$ \\
\hline
\end{tabular}

\section{KESIMPULAN}

Pemahaman proses bisnis lebih mudah dipahami jika dimodelkan dengan alur gambar/diagram alir/notasi model dibandingkan dengan verbal / teks.

1. Customer : Alur Gambar (Rich Picture)

2. Pegawai : Diagram Alir (Flow charts)

3. Pemilik Bisnis: Notasi Model (BPMN)

Pelaksaan proses bisnis lebih terlaksana dengan baik jika menggunakan notasi model dibandingakan dengan teks maupun diagram alir. Jika menggunakan teks dan flowcharts alur tahapan dan koordinasi kurang spesifik, belum details, tidak kompleks dan masih bersifat umum. Jika menggunakan BPMN, pengamatan dan pengawasan terhadap tahapan dan koordinasi lebih detail, spesifik dan kompleks sehingga mempermudah analisa dan evaluasi pelaksaan proses bisnis di lapangan. Untuk kedepannya diharapkan teknologi BPMN yang sudah ada dapat diperluas untuk proses bisnis pihak lain misalkan supplier, intermedier, dan sebagainya. Kemudian proses maupun alur bisnis yang sudah di modelkan ke dalam BPMN harus dijalankan sesuai dengan SOP yang sudah ditentukan, dan dilanjutkan dengan evaluasi terhadap pelaksanaannya di lapangan.

\section{DAFTAR PUSTAKA}

[2] I. Ismanto, F. Hidayah, and K. Charisma, "Pemodelan Proses Bisnis Menggunakan 
Business Process Modelling Notation (BPMN) (Studi Kasus Unit Penelitian Dan Pengabdian Kepada Masyarakat (P2KM) Akademi Komunitas Negeri Putra Sang Fajar Blitar)," Briliant J. Ris. dan Konseptual, vol. 5, no. 1, p. 69, 2020, doi: 10.28926/briliant.v5i1.430.

[3] D. Rosmala and Falahah, "PEMODELAN PROSES BISNIS B2B DENGAN BPMN (STUDI KASUS PENGADAAN BARANG PADA DIVISI LOGISTIK) Dewi," Snati, vol. 11, no. 1, pp. 40-50, 2007.

[4] A. D. Yulianto, "Perancangan Sistem Informasi Kemetrologian dalam Pendekatan Business Process Reengineering untuk Pelayanan Tera," Jnteti, vol. 03, no. 3, pp. 174-178, 2014.

[5] A. E. Prastya Nugraha and N. Wahyuhastuti, "Start Up Digital Business: Sebagai Solusi Penggerak Wirausaha Muda," J. Nusant. Apl. Manaj. Bisnis, vol. 2, no. 1, p. 1, 2017, doi: 10.29407/nusamba.v2i1.701.

[6] A. Lodhi, V. Küppen, and G. Saake, "An Extension of BPMN Meta-model for Evaluation of Business Processes," Sci. J. Riga Tech. Univ. Comput. Sci., vol. 43, no. 1, pp. 27-34, 2011, doi: 10.2478/v10143-011-00047.

[7] Nyata Nopiansah, "Implementasi Bpmn Untuk Membangun Model Bisnis Forensika Digital," no. December, 2019, doi: 10.31219/osf.io/hg724.

[8] D. M. D. U. Putra and Welda, "Business Process Analysis and Modeling Using the Business Process Improvement Framework at the Internal Quality Assurance STMIK STIKOM Indonesia," Int. J. Appl. Comput. Sci. Inform. Eng., vol. 1, no. 2, pp. 75-86, 2019, doi: 10.33173/acsie.53.

[9] R. Shapiro et al., BPMN 2.0 Handbook Second Edition: Methods, Concepts, Case Studies and Standards in Business Process Modeling Notation (BPMN). 2012.

[10] J. Zemguliene and M. Valukonis, "The International Journal ENTREPRENEURSHIP AND SUSTAINABILITY ISSUES STRUCTURED LITERATURE REVIEW ON BUSINESS PROCESS PERFORMANCE ANALYSIS AND EVALUATION The International Journal ENTREPRENEURSHIP AND SUSTAINABILITY ISSUES," Entrep. Sustain. Issues, vol. 6, no. 1, pp. 226-252, 2018, [Online]. Available: http://jssidoi.org/jesi/Publisherhttp://jssidoi.org /esc/homehttp://doi.org/10.9770/jesi.2018.6.1 \%0Ahttp://jssidoi.org/jesi/http://doi.org/10.977 0/jesi.2018.6.1.

[11] A. Cropley, Introduction to Qualitative Research Methods. Hamburg, Germany, 2015. 